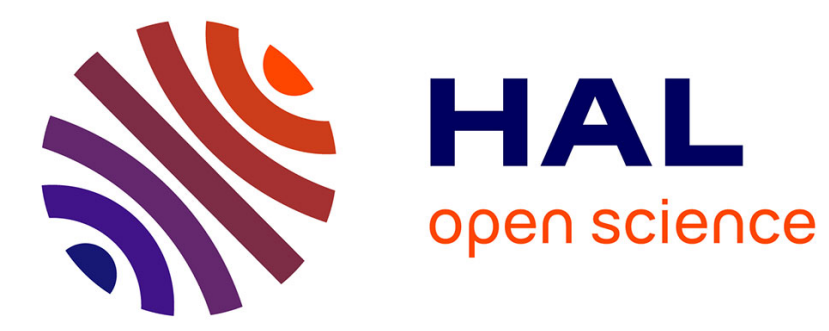

\title{
Spatial and temporal specific characterisation factors for water use impact assessment in Spain
}

\author{
M. Nunez Pineda, S. Pfister, M. Vargas, A. Anton
}

\section{To cite this version:}

M. Nunez Pineda, S. Pfister, M. Vargas, A. Anton. Spatial and temporal specific characterisation factors for water use impact assessment in Spain. International Journal of Life Cycle Assessment, 2015, 20 (1), pp.128-138. 10.1007/s11367-014-0803-5 . hal-01286103

\section{HAL Id: hal-01286103 \\ https://hal.science/hal-01286103}

Submitted on 10 Mar 2016

HAL is a multi-disciplinary open access archive for the deposit and dissemination of scientific research documents, whether they are published or not. The documents may come from teaching and research institutions in France or abroad, or from public or private research centers.
L'archive ouverte pluridisciplinaire HAL, est destinée au dépôt et à la diffusion de documents scientifiques de niveau recherche, publiés ou non, émanant des établissements d'enseignement et de recherche français ou étrangers, des laboratoires publics ou privés. 


\title{
Spatial and temporal specific characterisation factors for water use impact assessment in Spain
}

\author{
Montserrat Núñez ${ }^{\mathrm{a}, b^{*}}$, Stephan Pfister ${ }^{\mathrm{c}}$, Mar Vargas ${ }^{\mathrm{b}}$, Assumpció Antón ${ }^{\mathrm{b}, \mathrm{d}}$ \\ ${ }^{*}$ Corresponding author. E-mail address: montse.nunez-pineda@irstea.fr. \\ ${ }^{a}$ Irstea,UMR ITAP, ELSA-LCA research group, 361 rue Jean François Breton, F- \\ 34196, Montpellier, France. \\ ${ }^{b}$ IRTA, Ctra. de Cabrils, Km 2. E-08348 Cabrils, Barcelona, Spain. \\ ${ }^{c}$ ETH Zurich, Institute of Environmental Engineering, 8093 Zurich, Switzerland. \\ ${ }^{d}$ Departament d'Enginyeria Química. Universitat Rovira i Virgili (URV). 43003 \\ Tarragona, Spain.
}

\begin{abstract}
Purpose: Regionalised characterisation factors (CFs) for watersheds around the world are available to assess water-use-related environmental impacts. The main problem with using the watershed regionalisation level arises when a single $\mathrm{CF}$ is generated for large watersheds in countries where water availability and demand are not uniform. Additionally, water availability and use vary over time because of the effects of climate change and changing human lifestyles. These two factors are currently not taken into account in CFs, but should be included for the sake of the accuracy of LCA results. The aim of this research was to provide water stress index CFs at the sub-watershed spatial level for three temporal scenarios (present, short-term future and mid-term future) for Spain (Southern Europe), a country with considerably variability in water availability that is especially vulnerable to climate change effects.
\end{abstract}

Methods: CFs were calculated following the water stress index (WSI) definition of Pfister et al. (2009). The WSI was calculated on a yearly basis for 117 sub-watersheds - compared to 56 regionalisation units provided in the original method - and for (i) the current situation: current water use and availability; (ii) short-term future: projections for 2015; and (iii) mid-term future: projections for 2030. The uncertainties of the CFs were calculated for each sub-watershed.

Results and discussion: Temporal trend analysis of the CFs showed a general relaxation of water stress over the short-term when compared to the current situation, followed by a new increase. Major 
Author-produced version of the article published in International Journal of Life Cycle Assessment, 2015, №20(1), p. 128-138 The original publication is available at http://link.springer.com/article/10.1007/s11367-014-0803-5

Doi: 10.1007/s11367-014-0803-5

differences were noticed in the WSIs calculated by Pfister et al. (2009) using global data and maps and the WSIs calculated in this study using national and regional data. The WSIs under consideration of uncertainty were higher than the deterministic result for intermediate WSIs.

Conclusions and outlook: The CFs generated are useful compared with the CFs previously available because they improve evaluation of the water-use-related impacts of present and future technologies with the life cycle stages located in Spain. We encourage LCA developers to update WSIs for other countries using information at the national level that is usually freely accessible.

\section{KEYWORDS}

Climate change; freshwater use; life cycle impact assessment; regionalisation; water stress index; water footprint.

\section{INTRODUCTION}

Life cycle impact assessment (LCIA) of freshwater use and consumption has rapidly progressed over the last few years. Freshwater use is a generic term that groups all types of human uses of freshwater resources, while consumptive use is a specific type of freshwater use which denotes that water is removed from (i.e., withdrawn) but not returned to the same drainage basin (Bayart et al. 2010). The ILCD Handbook (JRC 2011) cautiously recommended (level III) the Swiss Ecoscarcity method (Frischknecht et al. 2009) for evaluating water-use-related environmental impacts in life cycle assessment (LCA) and indicated that this method was the only one that differentiated regional severity of water availability, interpreting water availability as the amount of the resource potentially useful for current users. The ILCD revision included all the impact methods published before 2009. Since then, numerous methods have been developed that provide a whole array of approaches covering many causality chains and taking into account issues related to both water quantity and quality degradation (Kounina et al. 2013). A common feature of all these methods is that they capture the uneven distribution of freshwater on earth through regionalisation, which means that characterisation factors (CFs) vary spatially. In consequence, within each spatial unit the characterisation factor, and thus the potential impact, of a quantity of resource used or a pollutant emitted, is the same. For water use in LCA, different regionalisation levels (e.g., archetypes of watersheds, watersheds, countries) are used in different methods (Kounina et al. 2013). So far, the watershed level of assessment appears to be the most accepted, as it is seen as the most effective spatial scale to address today's water resource 
Author-produced version of the article published in International Journal of Life Cycle Assessment, 2015, №20(1), p. 128-138 The original publication is available at http://link.springer.com/article/10.1007/s11367-014-0803-5

Doi: 10.1007/s11367-014-0803-5

management challenges (Environmental Protection Agency 2008; European Commission 2000).

Accordingly, water stress is defined by relating total water withdrawal or water consumption for human activities to renewable surface and ground water availability within the watershed. The higher the ratio, the more stress is placed on available water resources by water use or consumption. To calculate waterstress CFs, WaterGAP 2 (Alcamo et al. 2003) is the global water model used by several LCIA methods (Boulay et al. 2011; Pfister et al. 2009; Ridoutt and Pfister 2013). WaterGAP models global availability and water use at the watershed level and identifies the river basins where renewable water resources are under moderate stress and severe stress, which occurs when the withdrawal-to-availability (WTA) ratio is above $20 \%$ and $40 \%$, respectively (Alcamo et al. 2000). In WaterGAP 2, modelled water availability is an annual average for the 1961-1990 period and water withdrawals are estimated as an annual average for the years around 1995. Existing water-stress CFs used in LCA enhance this WTA ratio by accounting for seasonal effects on freshwater availability and the presence of reservoirs (Boulay et al. 2011; Pfister and Bayer 2014; Pfister et al. 2009). The main problem with using the watershed regionalisation level to assess water-use-related impacts arises when a single CF is generated for large watersheds, especially if the watersheds are in countries where water availability and water demand are not uniform. This is the case of Spain, a country with a strong gradient of water scarcity from north to south, as well as climate discrepancies between the Atlantic side (west) and the Mediterranean side (east). In accordance with WaterGAP 2, Spain (without considering the islands) is divided into 56 watersheds. Five of these watersheds (namely, the Duero, Ebro, Tajo, Guadalquivir and Guadiana watersheds, see Figure 1a) cover more than $65 \%$ of the area of the country and hold roughly $50 \%$ of the freshwater resources, which are distributed unevenly inside each watershed. Therefore, as pointed out by Loubet et al (2013), the quality of environmental assessments in a specific sub-region can be affected because of the different availability of water resources within these large watersheds.

Another limitation of WaterGAP 2 and statistical data sources is that they generally refer to past states, whereas current and future scenarios are relevant in LCA. One of the main consequences predicted of climate change is global water-cycle alteration. Regional water scarcity is expected to increase during the 21 st century in Spain and most other water-stressed-areas (IPCC 2007). Spain's geographic location makes it especially vulnerable to climate change and hence to reduced hydrologic resources and extreme climatic phenomena such as floods and droughts (Moreno et al. 2005). With this climate trend, as well as current and future changes in the economy and population that affect the volume of water withdrawals, the figures currently used to assess water stress in LCA should be updated 
Author-produced version of the article published in International Journal of Life Cycle Assessment, 2015, №20(1), p. 128-138 The original publication is available at http://link.springer.com/article/10.1007/s11367-014-0803-5

Doi: 10.1007/s11367-014-0803-5

periodically to correctly reflect the severity of water access at any given time and support optimised regional planning with regard to water-use-dependent environmental impacts.

This paper provides water scarcity-based CFs at the sub-watershed level for the largest watersheds in Spain (Duero, Ebro, Tajo, Guadalquivir and Guadiana). These CFs are provided to reduce the spatial uncertainty of water-use-indicator results for LCA studies when some or all of the product manufacturing processes take place in Spain. In addition, up-to-date data have been used to upgrade previously calculated CFs for the remaining watersheds in the country. The effects of climate change have been taken into account by developing water-scarcity CFs to be applied in present and future situations.

\section{MATERIALS AND METHODS}

\subsection{Water Stress Index characterisation factor}

To obtain water stress index characterisation factors at the sub-watershed scale, the Water Stress Index (WSI) methodology developed by Pfister et al. (2009) was used. This is one of the LCIA methods for water use in which midpoint CFs are based on the WaterGAP 2 withdrawal-to-availability (WTA) model. The WSI is calculated on a yearly basis. It takes continuous values from 0.01 to 1 . A WSI below 0.09 indicates low stress (WTA<0.2), a WSI from 0.09 to 0.5 indicates medium stress (WTA $<0.4$ ), a WSI from 0.5 to 0.91 indicates high stress (WTA $<0.6$ ) and a WSI from 0.91 to 1 indicates very high stress. All WSI over 0.5 are qualified as severe water stress (Pfister et al. 2009). WSIs are available for more than 10,000 watersheds worldwide. The formula for calculating the WSI for a specific watershed uses a modified WTA factor (WTA*, Equation 1). The WTA* introduces a variation factor (VF) that differentiates between watersheds with strongly regulated flows (SRF) affected by structures such as dams and reservoirs, and watersheds with non-strongly regulated flows. The VF depends on the intraand inter- annual precipitation variation (Equation 2). Finally, the yearly WSI is calculated by applying Equation 3.

$$
\begin{array}{ll}
\mathrm{WTA}^{*}=\left\{\begin{array}{cc}
\sqrt{\mathrm{VF}} \times \mathrm{WTA} \text { for SRF } \\
\mathrm{VF} \times \mathrm{WTA} \text { for non-SRF }
\end{array}\right. & \text { Equation 1 } \\
\mathrm{VF}=\mathrm{e}^{\sqrt{\ln \left(\mathrm{SD}_{\text {month }}\right)^{2}+\ln \left(\mathrm{SD}_{\text {year }}\right)^{2}}} & \text { Equation 2 } \\
\mathrm{WSI}=\frac{1}{1+e^{-6.4 W T A *}\left(\frac{1}{0.01}-1\right)} & \text { Equation 3 }
\end{array}
$$


Author-produced version of the article published in International Journal of Life Cycle Assessment, 2015, №20(1), p. 128-138 The original publication is available at http://link.springer.com/article/10.1007/s11367-014-0803-5

Doi: 10.1007/s11367-014-0803-5

In Spain, dams play an essential role in the regulation of water flows. The overall reservoir capacity amounts to 55,000 million $\mathrm{m}^{3}$ (MIMAM 2014). This makes it possible to regulate 46,000 million $\mathrm{m}^{3} /$ year, which is equivalent to more than $40 \%$ of the annual resource (Berga 2003). Given this, we assumed that all the watersheds in Spain had SRFs. This hypothesis was then tested in the uncertainty assessment (section 2.5 ), by assuming that $10 \%$ of water flows were non-regulated. The data sources used to calculate the new WSIs are described in section 2.4.

\subsection{Regionalisation units}

We calculated the WSIs following the method of Pfister et al. (2009) for the spatial units shown in Figure $1 \mathrm{~b}$. These regionalisation units are the sub-watersheds identified in the watershed management program prepared by each watershed management entity to implement the Water Framework Directive (WFD, European Commission 2000). We divided the five largest watersheds in Spain into 51 subwatersheds and obtained a total of 117 units in the country (Figure 1b). WaterGAP 2 contains 56 regionalisation units within Continental Spain (Figure 1a). Table 1S in the Electronic Supplementary Material (ESM) provides the list of the watershed identification codes in WaterGAP 2 used by Pfister et al. (2009) and the new codes given in this paper to facilitate the location and use of the new WSIs.

\section{Figure 1}

\subsection{Temporal scenarios}

To develop WSIs that could be used to predict impacts of long-term investments and future technologies and to evaluate how the combined effects of climate change on water availability and changing water use patterns can affect water stress in the future, we calculated CFs for three temporal scenarios (data sources presented in section 2.4):

(i) Current situation: based either on recent data of water use and availability measured and reported in statistics or on data estimated from measured and reported data. This is a retrospective scenario.

(ii) Short-term future scenario: based on projections of regional climate and hydrology models and the evolution of socioeconomic parameters influencing water uses (e.g., population growth and its geographic distribution, households, production, employment, income, etc.) in the year 2015. This is a prospective scenario.

(iii) Mid-term future scenario: the same as scenario (ii) but with a horizon of $\sim 2030$. 
Author-produced version of the article published in International Journal of Life Cycle Assessment, 2015, №20(1), p. 128-138 The original publication is available at http://link.springer.com/article/10.1007/s11367-014-0803-5

Doi: 10.1007/s11367-014-0803-5

\subsection{Data sources}

All the information needed to calculate the WSIs for the sub-watersheds highlighted in Figure 1 was obtained from their watershed management plans (references in ESM Table S2), which are a crucial tool of the European Union WFD to reach the environmental objectives in European water bodies. Data on annual water withdrawals for the current situation scenario are for around the year 2005-2010 (depending on the reporting watershed) and account for water used in households, industry and agriculture. Water withdrawals for the short-term and the mid-term future scenarios were projected for the years 2015 and 2027, respectively. The year 2027 was used as a proxy for water withdrawals for the mid-term future scenario ( 2030). The water resources available in the sub-watersheds of Spain may have different origins: internal natural sources (rivers, aquifers), internal artificial sources (desalinated water, regenerated wastewater) and external sources (transferred water). We only accounted for the internal natural sources within the available supply. Yearly water availability provided in the watershed plans was modelled using SIMPA (Integrated System for Rainfall-Runoff Modelling, Estrela et al. 1999; Ruiz 1998). This model includes several modules, one of which simulates the hydrological cycle and estimates the main variables involved. It is an implementation of a classic soil-moisture balance model. Two types of storage are considered (soil and aquifer) and transfer laws depending on parameters such as soil storage, maximum infiltration capacity and the aquifer discharge coefficient are taken into account. The spatial resolution is a gridded map with a cell size of $1 \mathrm{~km}^{2}$. The module operates for monthly periods, so yearly averages of the hydrologic variables are obtained by simple accumulation of monthly variables. Watershed management plans provide information on surface runoff, groundwater runoff and total runoff for two periods: October 1940 to September 2006 (long sequence) and October 1980 to September 2006 (short sequence). For the purpose of this study, we used the total runoff variable (i.e., surface runoff plus groundwater runoff) for the short temporal sequence to calculate water availability in the current situation. The short sequence was preferred over the long sequence because it includes the effects of climate change in the current situation scenario, as the end of the $20^{\text {th }}$ century and beginning of the $21^{\text {st }}$ century were an especially dry period in Spain. Mean annual and monthly rainfall statistics for the short temporal sequence were used to calculate the variation factor of the WTA* (Equations 1 and 2). Water availability for the short-term future and the mid-term future scenarios were estimated from expected future reductions in total runoff at the watershed scale compared to the runoff in the so-called climate normal period, which currently is the 30-year period from 1961 to 1990. Information on total runoff for the long sequence period (1940-2006) was used to calculate mean annual 
Author-produced version of the article published in International Journal of Life Cycle Assessment, 2015, №20(1), p. 128-138 The original publication is available at http://link.springer.com/article/10.1007/s11367-014-0803-5

Doi: 10.1007/s11367-014-0803-5

water availability for the climate normal period. Expected reductions in runoff due to the effects of climate change are reported in the watershed management programs for the year 2027 (i.e., the midterm future scenario) and a proportional reduction was calculated and assigned to the short-term future scenario. Figures of reduction in every scenario are shown in Table S2. The projection method on the potential impacts of climate change on hydrological resources uses future climate projections on rainfall, temperature, and potential evapotranspiration of regional climate models as starting point. Thereafter, climate parameters are linked to the hydrological model SIMPA to generate scenarios of future water availability (MIMAM and CEDEX 1998; Moreno et al. 2005). All the aforementioned data are reported in the watershed management plans at the same sub-watershed spatial scale used in this research paper, so no change in the spatial resolution level was required before calculations were made.

The WSIs of Pfister et al. (2009) for the rest of the watersheds in the country were updated for each temporal scenario (current, short-term and mid-term) by applying different assumptions. For water withdrawals, we assumed that water withdrawals from 1995 onward, as reported in WaterGAP 2, evolved in these watersheds at the same rate as in the country's five largest watersheds. According to this hypothesis, water withdrawals in the current situation scenario were 0.67 of those reported in WaterGAP 2 used by Pfister et al. (2009). Withdrawals in the short-term scenario were 1.04 of the withdrawals in the current situation. The increase is of 1.16 in the mid-term scenario compared to the current situation scenario. With regard to freshwater availability in these watersheds for the current situation scenario, as occurred for water withdrawals, it was assumed that the current available resource changed in the same proportion as in the five largest watersheds. This resulted in a resource reduction of $23 \%$ in the current situation compared to the availability reported in WaterGAP 2 (1961-1990). A discussion of the possible reasons for the drop in water abstraction and availability when comparing WaterGAP 2 figures and those obtained in this study is provided in the discussion section. The total water available in the two future scenarios was calculated as done for the five largest watersheds using percentages of the reduction per watershed published in MIMAM 2008; MIMAM and CEDEX 1998. These reductions are reported in ESM Table S2 and applied over the water availability in these watersheds for the climate normal period, as reported in WaterGAP 2. Because we did not have information on rainfall distribution for the smaller watersheds, the variation factors of the WTA* were estimated based on the VFs of the watersheds that were the closest of the five largest watersheds.

\subsection{Uncertainties}


Author-produced version of the article published in International Journal of Life Cycle Assessment, 2015, №20(1), p. 128-138 The original publication is available at http://link.springer.com/article/10.1007/s11367-014-0803-5

Doi: 10.1007/s11367-014-0803-5

Model and parameter uncertainties were estimated for each watershed. Model uncertainties are based on assessing the original supplemental material from Pfister et al. (2009), as described in Pfister and Hellweg (2011) for the WaterGAP-based WSIs. The uncertainty of the input data was estimated based on evaluation of the reported data sources. The input data and model uncertainties are summarised in Table 1, which includes the sources and assumptions for the estimates. Uncertainty of future and current model input is assumed to be equal.

\section{Table 1}

The model and parameter uncertainties were propagated to the WSI for each watershed using MonteCarlo simulation with 5,000 iterations (using Latin Hypercube sampling) with the software @Risk (Palisade 2011). Since the WSI range is limited between 0.01 and 1 , we changed all values under uncertainty over 1 to 1 and those below 0.01 to 0.01 . This was required, since the uncertainty attributed to the WSI function leads to probabilistic results above 1 and below 0.01 . As a statistical parameter for uncertainty, we reported the k-value (dispersion factor) according to Slob (1994) as the root of the ratio between the $97.5^{\text {th }}$ and the $2.5^{\text {th }}$ percentile. This can be compared to the square of the geometric standard deviation of a log-normal distribution often used in environmental science (Limpert et al. 2010).

However, according to Slob (1994), the dispersion factor can also be used to quantify uncertainties and propagate errors without evidence for log-normal distribution, provided that it is a multiplicative model. However, since the result of the WSI function can only range between 0.01 and 1 , we used an average measure for $\mathrm{k}$ and also included the ratio of the $97.5^{\text {th }}$ percentile to the median and the ratio of the median to the $2.5^{\text {th }}$ percentile, since this would be the same in a log-normal distribution. We therefore found a more robust estimate of $\mathrm{k}$. Additionally, we have reported the uncertainty information as the standard deviation of all runs.

Another part of the uncertainty assessment is the comparison of the median, arithmetic average and mode to the deterministic quantification of the WSI. For this task, the median and arithmetic mean of the 5,000 results between 0.01 and 1 were used, whereas for the mode, the 5,000 results not limited between 0.01 and 1 were used, since either 0.01 or 1 would otherwise typically be the mode, which is not representative as an indicator of the expected value. 


\section{RESULTS}

\subsection{Evolution of Water Stress Index characterisation factor}

Figure 2 illustrates the WSI CFs obtained for the current scenario (Fig. 2a) and projected for the short-term future scenario (Fig. 2b) and mid-term future scenario (Fig. 2c) at the sub-watershed level. The three temporal scenarios demonstrate the known uneven geographic distribution of the environmental pressure on freshwater resources in Spain: in the northwest, more water is available for competing uses and the WSIs in most regions are therefore lower than 0.5. However, towards the southeast, the severity of access to the resource steadily raises, and WSIs are greater than 0.5 in almost all sub-watersheds. Temporal trend analysis of the CFs showed a general relaxation of water stress in the short-term future scenario when compared to the current situation due to an increase in water resources availability. This is followed by a new increase of stress due to the combination of increase in water use and the reduction in water availability (see ESM Table S1 for further details). The comparison of the current situation and the short-term future scenario (Fig. $2 \mathrm{a}$ and $2 \mathrm{~b}$ ) showed a drop from $23 \%$ to $19 \%$ in the number of sub-watersheds under very high stress (WSI $>0.91$ ). The area-weighted WSI for Spain was 0.54 in the current situation and 0.48 in the short-term future scenario. In the mid-term future scenario, the amount of sub-watersheds facing very high stress increased to the same level experienced in the current situation (23\%) and the proportion of sub-watersheds with high and very high water stress (WSI $>0.5$ ) increased from $33 \%$ to $36 \%$. In this temporal scenario, the area-weighted WSI once again increased to 0.55 .

Table 2 provides details of the evolution of water withdrawal, water availability and the WTA and WSI indices for the five largest watersheds in Spain. In all watersheds and scenarios irrigation is the largest water use sector, accounting for $60 \%-95 \%$ of total extractions. This figure indicates that agricultural water use is expected to preserve its important role in Spain in the coming future. The dynamic of other factors, such as changes in population and income, are less important in determining total water withdrawals when compared to agriculture. From the current scenario to the short-term future scenario, water withdrawals showed different trends in the watersheds. Some watersheds plans reported an increase in water use, especially due to either a rise of extractions for agriculture (e.g., Guadiana watershed) or to the population growth (e.g., Tajo watershed). In other watersheds, such as the Duero and Guadalquivir ones, the introduction of water-saving measures in agriculture are reported to be able to reduce the demand of water to a lower level than within the current scenario and the business- 
Author-produced version of the article published in International Journal of Life Cycle Assessment, 2015, №20(1), p. 128-138 The original publication is available at http://link.springer.com/article/10.1007/s11367-014-0803-5

Doi: 10.1007/s11367-014-0803-5

as-usual scenario (i.e., if current scenario trends in technology and human behaviour continue without changes). In the Duero watershed, the stagnation of population growth and lower consumption per capita in the urban sector also contributes to the drop in water extraction. Water resource availability from the current scenario to the short-term future increased in all watersheds by $\sim 10 \%-25 \%$ due to greater precipitation. As a result, the withdrawal-to-availability ratio from the current to the short-term future scenario showed an average reduction of nearly $15 \%$ and the WSI showed an average reduction of around $25 \%$. From the short-term future to the mid-term future scenario, water withdrawals increase ( $\sim 5 \%-25 \%)$ because technology cannot compensate for population growth and the expansion of new irrigation areas. Especially relevant is the case of the Ebro river basin, where the development of a vast irrigation area (the Segarra-Garriga canal) is responsible for a rise of more than $25 \%$ in water use. Also, a reduction in water availability $(\sim 2 \%-4 \%)$ is predicted from the short-term future to the mid-term future. Accordingly, WTA and WSI ratios reverted to the trend of the current situation and went up to approximately the same level. The original and new WSIs developed here are compared in the discussion section.

Figure 2

Table 2

\subsection{Uncertainties}

Figure 3 presents the uncertainty information for each sub-watershed for the current scenario. The standard deviation was higher than 0.1 in most regions, except the northwest, where water is abundant and WSIs are low (Figure 3a). Low WSIs are less sensitive to uncertainties. The highest standard deviation was reported for areas of moderate water stress, whereas regions with very high water stress tended to have lower standard deviations, since the values were limited to 1 . This is even more important when k-factors are considered (Figure 3b): k-factors describe multiplicative uncertainty ranges (i.e., relative to the WSI), which means that a standard deviation of e.g., 0.1 become low for large WSIs and high for small WSIs. In a combined assessment, the results show that WSI values between 0.05 and 0.5 were the most sensitive to uncertainties in input data and model parameters, as shown in Figure 4. This graph also shows that the anticipated value using stochastic error propagation was much higher when the deterministic WSI $<0.8$ (for the median, mean and mode). It was typically more than double the deterministic WSI when the WSI $<0.2$ (for the mean and median). One reason for this is the fact that we assumed that $10 \%$ of flows were not regulated (as a result of the binomial 
Author-produced version of the article published in International Journal of Life Cycle Assessment, 2015, №20(1), p. 128-138 The original publication is available at http://link.springer.com/article/10.1007/s11367-014-0803-5

Doi: 10.1007/s11367-014-0803-5

distribution) and hence had a higher variation factor (see Equation 1) compared to the deterministic result. When the deterministic WSI $>0.8$, the stochastic estimation provided lower values, since the WSI function is limited to 1 . Variability was therefore only possible below 1 and anticipated values were lower, especially for the mean.

Figure 3

Figure 4

\section{DISCUSSION}

We have updated and refined the spatial resolution of WSI CFs developed by Pfister et al. (2009) for Spain. All the information we used to calculate the revised CFs was taken from two kinds of sources at the national and regional level: on the one hand, the watershed management plans prepared by each watershed management entity to comply with the requirements established by the Water Framework Directive, and, on the other hand, reports published by the Spanish Ministry of Environment (MIMAM and CEDEX 1998; MIMAM 2008; Moreno et al. 2005) on potential scenarios of environmental impacts in Spain due to the effects of climate change. The same type of publicly available information used here to calculate new CFs for Spain should be available in every EU country to meet European environmental policies. Similar kinds of regulations for protecting bodies of water exist in other parts of the world, especially in mostly industrialised countries (e.g., the Clean Water Act in United States, Water Quality Policy in Australia). This means that adjustment of the WSI CFs of Pfister et al. (2009)'s for the present and future previsions at the sub-watershed regionalisation level can be carried out in developed countries without major difficulties when it comes to accessing necessary data. More problems for updating might be expected in developing countries because of constraints of data availability.

WSIs for small watersheds in Spain $(<35 \%$ of the area of the country) were updated to the current scenario assuming the same rate of change in water use and availability than in the five largest watersheds covering $>65 \%$ of the area. A more accurate procedure would have been to find up-to-date, watershed-specific information on water use and availability and develop WSIs using this data. However, this would have required substantial data gathering effort only to come up with a potentially inconsistent update, but not with an improvement of the spatial resolution of the CFs, which is already on sub-watershed level. We expect the gain in accuracy to be small due to further sources of uncertainty (e.g., statistical data sources, water availability model, etc.) affecting the detailed update of WSIs, which 
Author-produced version of the article published in International Journal of Life Cycle Assessment, 2015, №20(1), p. 128-138 The original publication is available at http://link.springer.com/article/10.1007/s11367-014-0803-5

Doi: 10.1007/s11367-014-0803-5

means that from a practical point of view the additional effort is not justified. Therefore, we recommend using the up-to-date WSIs for small watersheds generated in this work instead of those provided in Pfister et al. (2009) for the past.

The WTA ratios for the five largest watersheds in Spain reported in WaterGAP 2 and used by Pfister et al. (2009) to calculate WSIs (the past in Table 2) were compared to WTA ratios and WSIs obtained here. To do so, water withdrawal and availability in watersheds of WaterGAP 2 partially shared with neighbouring Portugal were proportionally assigned to Spain and Portugal based on the watershed area in each country. Also, water withdrawal and availability at the sub-watershed level in this work were summed up to obtain total water demand and supply in each of the largest watersheds. Major differences were observed between the WSIs calculated by Pfister et al. (2009) using global data and maps and the WSIs calculated in this study using national and regional data. This may be because water availability is calculated using two different hydrological models. Indeed, total available runoff for the climate normal period in WaterGAP 2 is from $30 \%$ lower to $20 \%$ greater than in SIMPA, depending on the reporting watershed. WaterGAP 2 and SIMPA model the terrestrial water cycle by calculating water balances for the different processes from precipitation to runoff of water in each grid cell. However, parameterisation of flows and spatial and temporal resolution in each model is different. WaterGAP 2 has cells of $0.5^{\circ}$ and operates for daily time steps, while SIMPA has greater spatial resolution (cells of $0.009^{\circ}$, i.e., $1 \mathrm{~km}^{2}$ ) but lower temporal detail (monthly time step). The resolution of the model governs its capacity to describe soil and climate variations, hence water yield of a cell. Also regarding the spatial resolution, both hydrological models have cells aggregated into watersheds. However, delineation of watersheds in every model is different, and so is the amount of water available within the borders of a concrete unit. Consequently, different spatial resolutions yield different WTA ratios and WSIs, which explains why WSIs calculated by Pfister et al. (2009) and those from this work vary. Differences between the WSIs may also be explained by the different geographical representativeness of the input data used in the calculations, which is reflected by greater uncertainties in the original WSIs (arithmetic mean k-dispersion factor for Spain $=3.2$ ) compared to the new ones (arithmetic mean k-dispersion factor $=2.9$ ). We observed differences in uncertainties compared with Pfister et al. (2009), but they would have been greater if Pfister et al. (2009) had not done aggregation in larger watersheds, since spatial aggregation conceals the temporal variability of precipitation, which leads to lower VFs. Another potential source of difference between the WSIs in both studies may be the fact that they were calculated for different time periods, with changing environments (i.e., water availability), freshwater 
Author-produced version of the article published in International Journal of Life Cycle Assessment, 2015, №20(1), p. 128-138 The original publication is available at http://link.springer.com/article/10.1007/s11367-014-0803-5

Doi: 10.1007/s11367-014-0803-5

use patterns and efficiencies. In general, the water withdrawals, water availability and WSIs calculated for the past scenario were considerably greater than in our present and near future scenarios.

Accordingly, the arithmetic mean \pm standard deviation of the WSI for the whole country was $0.51 \pm 0.46$ for the WaterGAP-based WSI in 1995 (considering only the sections in Spain of the watersheds). It dropped to $0.27 \pm 0.41$ in the current situation and $0.34 \pm 0.40$ in the short-term future scenario and $0.38 \pm 0.42$ in the mid-term future scenario. Especially noteworthy is the case of the Guadalquivir watershed, which showed a reported reduction in 55\% of water use from 1995 to 2005 (Table 2). Even though this drop in water use could be an overestimation of reality, water withdrawal has tended downward in many developed countries over the last decade thanks to water-efficient technologies and the environmental awareness of society. As a result, the differences between physical water scarcity measured using withdrawal-based indicators (WTA) and consumption-based indicators (CTA) are becoming progressively lower. This adds to the ongoing discussion of which of the two approaches is more suitable for reflecting water-stress situations (Berger and Finkbeiner 2013; Boulay et al. submitted; Hoekstra et al. 2012; Loubet et al. 2013). Another factor worthy of notice when WaterGAPbased WSIs and the WSIs generated in this study are compared is the sharp drop from WSI $=0.99$ to WSI $=0.52$ experienced in the Guadiana watershed, whereas the WTA did not diminish in the same proportion. The global maps used in Pfister et al. (2009) assumed that the rivers in the Guadiana watershed were not strongly regulated, which was reflected by a high VF value (Equation 1) and eventually by an increase in the annual water-stress index. However, the Guadiana watershed is the second most regulated in the country with roughly 8,600 million $\mathrm{m}^{3}$ of reservoir capacity (MIMAM 2013). Based on this, we believe that the original WSI was overestimated and recommend using the new values obtained here, which rely on national data sources instead of global information.

The results obtained in this study show, with the inherent uncertainties of the predictions and data used, that the severity to access freshwater resources by competing uses in Spain is not worse now and will not become worse in the first third of the 21 st century compared to the recent past, as illustrated by the evolution of the WSI. The first reason is the general reduction in water withdrawals at present and in the near future compared to the late 20th century (Table 2). It should be noted that expected effects of climate change in crop evapotranspiration were not modelled in the future scenarios. The second reason is the enhanced water availability in the near future compared to the present situation (Table 2, see watershed management plans for further details, Table S2). This can be explained because predicted total annual rainfall will increase in the future compared to the 1980-2005 period (MIMAM and 
Author-produced version of the article published in International Journal of Life Cycle Assessment, 2015, №20(1), p. 128-138 The original publication is available at http://link.springer.com/article/10.1007/s11367-014-0803-5

Doi: 10.1007/s11367-014-0803-5

CEDEX 1998), which was a dry period in Spain. However, individual climatic models differ as to the predictions given for rainfall trends in Spain, so results for an increase in water resources are uncertain (Moreno et al. 2005). From 2030 onward, temporal series show a continuous reduction in water availability in Spain of 5\%-34\% until 2070 and 0\%-40\% until 2100 (MIMAM and CEDEX 1998). To avoid water-stress intensification (i.e., higher WSIs), mitigation options should aim at optimising demand management (i.e., less water withdrawal), and increasing rainwater harvesting and so-called artificial sources (regenerated wastewater, desalinated water). While withdrawal reduction based on increased efficiency does not contribute to lower consumption, non-conventional sources can be considered negative use/consumption in the life cycle inventory (LCI) or can be characterised with $\mathrm{CF}=0$ in the LCIA, as justified by Hospido et al. (2013). Including non-conventional sources in the WSI helps improve the water stress of a specific watershed.

When comparing the WSI CFs developed by Pfister et al. (2009) for Spain and the new CFs, spatial specifications passed from the watershed to the sub-watershed scale in the largest part of the country. Other authors have already discussed the importance of the location of withdrawal within a watershed to determine the magnitude of impacts on aquatic biodiversity (Tendall et al. 2013) and have proposed sophisticated approaches to determine the downstream cascade effects of consumption within a watershed, depending on where it occurs (Loubet et al. 2013; Tendall 2013; Verones et al. 2013). To apply our WSI CFs, as well as other methods resolved at detailed spatial scales, the LCA practitioner should know the location of freshwater withdrawal within the watershed, which is usually restricted to the foreground processes of the full product's life cycle. For background processes, spatial data information on the LCI is usually vague or, in the worst case scenario, unavailable. To assess these processes and for the sake of consistency with the CFs developed here, we recommend using the WSIs by Pfister et al. (2009) for the world at the watershed, country and unspecific spatial scale until more specific WSIs with global coverage are developed.

This study provides insight into the importance of considering higher spatial detail than country and watershed level when assessing freshwater use-related impacts in Spain. This is in line with the recommendations given in Boulay et al. (submitted). Besides this improvement, information already publicly available at the national and regional level in Spain and, by extension, EU countries, can be used to further refine WSIs at higher temporal resolution (per month rather than per year), as developed at the global level by Pfister and Bayer (2014), and to distinguish between surface and groundwater use/consumption. Water quality factors are also described in watershed management plans, which 
Author-produced version of the article published in International Journal of Life Cycle Assessment, 2015, №20(1), p. 128-138 The original publication is available at http://link.springer.com/article/10.1007/s11367-014-0803-5

Doi: 10.1007/s11367-014-0803-5

means that even more complex indicators that include water-quality parameters (e.g., Boulay et al. 2011) may be applied using local data. Likewise, watershed management plans include a first approximation on the environmental water requirements (EWRs) of freshwater-dependent ecosystems, such as used in the water stress assessment by Milà i Canals et al. (2009). Improving hydrological models to reduce the high level of uncertainty of these calculations is a priority.

We have shown that the uncertainties of WSI factors have a standard deviation of between 0.15 and 0.3 , which is quite high considering the scale from 0.01 to 1 . As mentioned above, hydrological models make a considerable contribution to overall uncertainty, given that they are not overly robust.

Additionally, the WSI function is considered to be uncertain. This also includes the uncertainty of addressing withdrawal-to-availability vs. consumption-to-availability.

It is not clear whether the standard deviation or the $\mathrm{k}$-factor is a more relevant uncertainty measure. In principle, the confidence intervals of interest can be directly derived from the stochastic estimate. If we take a global perspective, where WSI of different regions are compared, the standard deviation is more representative, as it indicates the uncertainty in the unit of WSI. In LCA, the inventory is often characterized by multiplicative uncertainty information and k-factors are therefore more consistent with inventory uncertainty. In any case, low and moderate WSIs are most sensitive to uncertainties, which is also a feature of the logistic function (higher sensitivity when the slope of the function is steep).

\section{CONCLUSIONS}

We calculated water stress-based characterisation factors for sub-watersheds in Spain by increasing the spatial resolution of currently available methods. Moreover, for the first time, CFs were calculated for three temporal steps: the current situation, which provides WSIs to assess potential impacts of current water uses, and two future time periods, with WSIs to predict impacts of consumption and production in the near future and in the year 2030. The CFs were calculated following the Water Stress Index (WSI) definition of the method of Pfister et al. (2009), so the consistency of CFs developed in our study and those provided in the aforementioned method was assured. The same revision of WSIs done for Spain should be possible with a reasonable amount of effort in all European Union member states and other industrialised countries, thanks to the information made publicly available to comply with the regulatory requirements.

In spite of the unavoidable uncertainties of future predictions, temporal variations in water withdrawal and the effects of climate change on regional water availability have to be included in the 
Author-produced version of the article published in International Journal of Life Cycle Assessment, 2015, №20(1), p. 128-138 The original publication is available at http://link.springer.com/article/10.1007/s11367-014-0803-5

Doi: 10.1007/s11367-014-0803-5

calculation of water-use CFs. As shown in this study, temporal and spatial specification matters when long-term decisions and future technologies are evaluated regarding water-use-related impacts.

\section{ACKNOWLEDGEMENTS}

This research was funded by the Spanish Ministry of Economy and Competitiveness and the European Regional Development Fund within the framework of the Decocel Innpacto Project (IPT-2011-1220920000). The authors thank the anonymous technicians at the Spanish watershed management organisations for their support. M. Núñez gratefully acknowledges the financial support of the partners in the Industrial Chair for Life Cycle Sustainability Assessment ELSA-PACT: Suez Environment, Société du Canal de Provence (SCP), Compagnie d'aménagement du Bas-Rhône et du Languedoc (BRL), Val d'Orbieu - UCCOAR, EVEA, ANR, Irstea, Montpellier SupAgro, École des Mines d'Alès, CIRAD, ONEMA, ADEME, and the Region Languedoc - Roussillon. She is a member of the ELSA research group and thanks all the members of ELSA for their advice.

\section{ELECTRONIC SUPPLEMENTARY MATERIAL}

Supplementary material includes an ".XLS” file with detailed water use and availability flows, WTAs and WSIs per sub-watershed, and links to the online documents (in Spanish) used to calculate water flows in each watershed. The material also contains a ".SHP” file (geographical information system file) specifying the location of each watershed and sub-watershed.

\section{REFERENCES}

Alcamo J, Döll P, Henrichs T, Kaspar F, Lehner B, Rösch T, Siebert S (2003) Global estimates of water withdrawals and availability under current and future "business-as-usual" conditions. Hydrol Sci J 48(3):339-348

Alcamo J, Henrichs T, Rösch T (2000) World Water in 2025 - Global modeling and scenario analysis for the World Commission on Water for the 21st Century. Report 0002, Center for Environmental Systems Research, University of Kassel, Kassel

Bayart JB, Bulle C, Deschênes L, Margni M, Pfister S, Vince F, Koehler A (2010) A framework for assessing off-stream freshwater use in LCA. Int J Life Cycle Assess 15(5): 439-453

Berga L (2003) Presas y embalses en la España del siglo XXI. Revista de Obras Públicas 3438:37-40 
Author-produced version of the article published in International Journal of Life Cycle Assessment, 2015, №20(1), p. 128-138 The original publication is available at http://link.springer.com/article/10.1007/s11367-014-0803-5

Doi: 10.1007/s11367-014-0803-5

Berger M, Finkbeiner M (2013) Methodological challenges in volumetric and impact-oriented water footprints. J Ind Ecol 17(1):78-89

Boulay AM, Bulle C, Bayart JB, Deschênes L, Margni M (2011) Regional characterization of freshwater use in LCA: modeling direct impacts on human health. Environ Sci Technol 45:89488957

Boulay AM, Motoshita M, Pfister S, Bulle C, Muñoz I, Franceschini H, Margni M (submitted) Analysis of water use impact assessment methods (part A): evaluation of modelling choices based on a quantitative comparison of scarcity and human health indicators. Int J Life Cycle Assess

Environmental Protection Agency (2008) Handbook for Developing Watershed Plans to Restore and Protect Our Waters. Washington DC

Estrela T, Cabezas F, Estrada F (1999) La evaluación de los recursos hídricos en el Libro Blanco del Agua en España. Ing del Agua 6(2):125-138

European Commission (2000) Directive 2000/60/EC of the European Parliament and of the Council of 23 October 2000 establishing a framework for Community action in the field of water policy. Offical Journal of the European Communities, 22.12.2000

Frischknecht R, Steiner R, Jungbluth N (2009) The Ecological Scarcity Method. Eco-factors 2006. A method for impact assessment in LCA. Bern

Hoekstra AY, Mekonnen MM, Chapagain AK, Mathews RE, Richter BD (2012) Global monthly water scarcity: blue water footprints versus blue water availability. PLoS One 7(2): 9 pp

Hospido A, Núñez M, Antón A (2013) Irrigation mix: how to include water sources when assessing freshwater consumption impacts associated to crops. Int J Life Cycle Assess 18(4):881-890 IPCC (2007) Climate change 2007: The physical science basis. Solomon S, Qin D, Manning M, Chen Z, Marquis M, Averyt KB, Tignor M, Miller HL (ed) Cambridge University Press, Cambridge, United Kingdom and New York, United States

JRC (2011) ILCD handbook. Recommendations for Life Cycle Impact Assessment in the European context. Luxemburg

Kounina A, Margni M, Bayart JB, Boulay AM, Berger M, Bulle C, Frischknecht R, Koehler A, Milà i Canals L, Motoshita M, Núñez M, Peters G, Pfister S, Ridoutt B, van Zelm R, Verones F, Humbert S (2013) Review of methods addressing freshwater use in life cycle inventory and impact assessment. Int J Life Cycle Assess 18(3):707-721 
Author-produced version of the article published in International Journal of Life Cycle Assessment, 2015, №20(1), p. 128-138 The original publication is available at http://link.springer.com/article/10.1007/s11367-014-0803-5

Doi: 10.1007/s11367-014-0803-5

Limpert E, Stahel WA, Abbt M (2010) Log-normal distributions across the sciences: Keys and clues. Biosci 51(5):341-352

Loubet P, Roux P, Núñez M, Belaud G, Bellon-Maurel V (2013) Assessing water deprivation at the sub-river basin scale in LCA integrating downstream cascade effects. Environ Sci Technol 47(24):14242-14249

Milà i Canals L, Chenoweth J, Chapagain A, Orr S, Antón A, Clift R (2009) Assessing freshwater use impacts in LCA: Part I-inventory modelling and characterisation factors for the main impact pathways. Int J Life Cycle Assess 14(1): 28-42

MIMAM (2008) ORDEN ARM/2656/2008, de 10 de septiembre por la que se aprueba la instrucción de planificación hidrológica. Spanish Official Bulletin no 229, pp 38472-38582 http://www.boe.es/boe/dias/2008/09/22/pdfs/A38472-38582.pdf. Accessed 18 June 2014

MIMAM (2014) Estado de los embalses y pantanos de España. http://www.embalses.net/. Accessed 2 July 2014

MIMAM, CEDEX (1998) Evaluación del impacto del cambio climático en los recursos hídricos en régimen natural. Madrid. http://www.magrama.gob.es/es/cambioclimatico/publicaciones/publicaciones/Memoria_encomienda_CEDEX tcm7-165767.pdf. Accessed 18 June 2014

Moreno J, Aguiló E, Alonso S, Álvarez-Cobelas M, Anadón R, Ballester F et al (2005) A preliminary general assessment of the impacts in Spain due to the effects of climate change. Spanish Ministry of the Environment, Madrid

Palisade (2011) @ Risk 2011. http://www.palisade.com/risk/. Accessed 21 January 2014

Pfister S, Bayer P (2014) Monthly water stress: spatially and temporally explicit consumptive water footprint of global crop production. J Clean Prod 73:52-62.

Pfister S, Hellweg S (2011) Surface water use - human health impacts. Report of the LC-IMPACT project (EC: FP7). http://www.ifu.ethz.ch/ESD/downloads/Uncertainty_water_LCIA.pdf. Accessed 23 January 2014

Pfister S, Koehler A, Hellweg S (2009) Assessing the environmental impacts of freshwater consumption in LCA. Environ Sci Technol 43(11):4098-4104 
Author-produced version of the article published in International Journal of Life Cycle Assessment, 2015, №20(1), p. 128-138 The original publication is available at http://link.springer.com/article/10.1007/s11367-014-0803-5

Doi: 10.1007/s11367-014-0803-5

Ridoutt BG, Pfister S (2013) A new water footprint calculation method integrating consumptive and degradative water use into a single stand-alone weighted indicator. Int J Life Cycle Assess 18(204-207):204-207

Ruiz García JM (1998) Desarrollo de un modelo hidrológico conceptual distribuido de simulación continua integrado en un SIG. Dissertation, Universidad Politécnica de Valencia

Slob W (1994) Uncertainty Analysis in Multiplicative Models. Risk Anal 14(4):571-576

Tendall D (2013) Life cycle assessment of Swiss agriculture under climate change and the impacts of water use on aquatic biodiversity. Dissertation, ETH. http://dx.doi.org/10.3929/ethz-a-009962954. Accessed 23 January 2014

Tendall DM, Raptis C, Verones F (2013) Water in life cycle assessment - 50th Swiss Discussion Forum on Life Cycle Assessment—Zürich, 4 December 2012. Int J Life Cycle Assess 18(5): 1174-1179

Verones F, Pfister S, Hellweg S (2013) Quantifying area changes of internationally important wetlands due to water consumption in LCA. Environ Sci Technol 47(17):9799-9807 
Author-produced version of the article published in International Journal of Life Cycle Assessment, 2015, №20(1), p. 128-138 The original publication is available at http://link.springer.com/article/10.1007/s11367-014-0803-5

Doi: 10.1007/s11367-014-0803-5

\section{TABLES}

Tab 1. Overview of estimated uncertainties and respective assumptions.

\begin{tabular}{|c|c|c|c|c|c|c|}
\hline & Withdrawals & Availability & Flow regulation & $\begin{array}{l}\text { Variation factor } \\
\text { (VF) }\end{array}$ & $\begin{array}{l}F^{*} \\
\text { (estimate for } \\
\text { small } \\
\text { watersheds) }\end{array}$ & $\begin{array}{l}\text { WSI } \\
\text { function }\end{array}$ \\
\hline $\begin{array}{l}\text { Uncertainty } \\
\text { function }\end{array}$ & $\begin{array}{l}\text { Log-normal } \\
\text { distribution }\end{array}$ & $\begin{array}{l}\text { Log-normal } \\
\text { distribution }\end{array}$ & $\begin{array}{l}\text { Binominal } \\
\text { distribution }\end{array}$ & $\begin{array}{l}\text { Log-normal } \\
\text { distribution }\end{array}$ & $\begin{array}{l}\text { Log-normal } \\
\text { distribution } \\
\text { for estimated } \\
\text { watershed VF }\end{array}$ & \\
\hline Value & $\mathrm{k}=1.15$ & $\mathrm{k}=1.08-1.58$ & $\mathrm{SRF}=[0.9 ; 0.1]$ & $\mathrm{k}=\mathrm{VF}^{*}$ & $\begin{array}{l}\mathrm{k}=1.3 \text { for } \\
\text { smaller } \\
\text { watersheds } \\
\text { ( } \mathrm{k}=1 \text { for the } 5 \\
\text { largest } \\
\text { watersheds) }\end{array}$ & $\mathrm{k}=1.7$ \\
\hline Source & $\begin{array}{l}\text { Based on Pfister } \\
\text { and Hellweg } \\
(2011)(\mathrm{k}=1.2 \\
\text { for Spain]) } \\
\text { Assuming greater } \\
\text { robustness of } \\
\text { Water } \\
\text { Deprivation } \\
\text { Factor (WDF) } \\
\text { data }\end{array}$ & $\begin{array}{l}\text { Based on } \\
\text { analysis of } \\
\text { waterGAP } 2 \text { and } \\
\text { reported data }\end{array}$ & $\begin{array}{l}\text { Based on Pfister } \\
\text { and Hellweg } \\
(2011) \\
([0.8 ; 0.2]) \text {. } \\
\text { Assuming } \\
\text { greater } \\
\text { robustness of } \\
\text { SRF estimate } \\
\text { due to reports }\end{array}$ & $\begin{array}{l}\text { Based on Pfister } \\
\text { and Hellweg } \\
\text { (2011) }\end{array}$ & $\begin{array}{l}\text { Assessment } \\
\text { of variability } \\
\text { of VF in } \\
\text { Spain (for } \\
\text { estimates of } \\
\text { small } \\
\text { watersheds) }\end{array}$ & $\begin{array}{l}\text { Based on } \\
\text { Pfister and } \\
\text { Hellweg } \\
\text { (2011) }\end{array}$ \\
\hline
\end{tabular}


Author-produced version of the article published in International Journal of Life Cycle Assessment, 2015, №20(1), p. 128-138 The original publication is available at http://link.springer.com/article/10.1007/s11367-014-0803-5

Doi: 10.1007/s11367-014-0803-5

Tab 2. Temporal trend for the large five watersheds in Spain of water withdrawal (WW), water availability (WA), water-toavailability (WTA), water stress index (WSI)

\begin{tabular}{|c|c|c|c|c|c|}
\hline & Duero & Ebro & Guadalquivir & Guadiana & Tajo \\
\hline \multicolumn{6}{|l|}{ Past (1995) } \\
\hline WW $\left(10^{6} \mathrm{~m}^{3} \mathrm{y}^{-1}\right)$ & 6528 & 7652 & 8512 & 3835 & 6184 \\
\hline WA $\left(10^{6} \mathrm{~m}^{3} \mathrm{y}^{-1}\right)$ & 18482 & 16061 & 6206 & 6520 & 12464 \\
\hline WTA (-) & 0.35 & 0.48 & 1.37 & 0.59 & 0.50 \\
\hline WSI (-) & 0.17 & 0.26 & 1.00 & 0.99 & 0.53 \\
\hline \multicolumn{6}{|l|}{ Current (2005) } \\
\hline WW $\left(10^{6} \mathrm{~m}^{3} \mathrm{y}^{-1}\right)$ & 4800 & 8185 & 3800 & 2218 & 3313 \\
\hline WA $\left(10^{6} \mathrm{~m}^{3} \mathrm{y}^{-1}\right)$ & 12388 & 14623 & 5754 & 4591 & 7874 \\
\hline WTA (-) & 0.39 & 0.56 & 0.66 & 0.48 & 0.42 \\
\hline WSI (-) & 0.19 & 0.39 & 0.93 & 0.52 & 0.31 \\
\hline \multicolumn{6}{|c|}{ Short-term future (2015) } \\
\hline $\mathrm{WW}\left(10^{6} \mathrm{~m}^{3} \mathrm{y}^{-1}\right)$ & 4101 & 9327 & 3593 & 2627 & 3518 \\
\hline WA $\left(10^{6} \mathrm{~m}^{3} \mathrm{y}^{-1}\right)$ & 13925 & 16712 & 7574 & 5351 & 9960 \\
\hline WTA (-) & 0.29 & 0.56 & 0.47 & 0.49 & 0.35 \\
\hline WSI (-) & 0.10 & 0.38 & 0.63 & 0.53 & 0.19 \\
\hline \multicolumn{6}{|c|}{ Mid-term future (2030) } \\
\hline WW $\left(10^{6} \mathrm{~m}^{3} \mathrm{y}^{-1}\right)$ & 5352 & 10586 & 3800 & 2790 & 3697 \\
\hline WA $\left(10^{6} \mathrm{~m}^{3} \mathrm{y}^{-1}\right)$ & 13635 & 16284 & 7374 & 5149 & 9517 \\
\hline WTA (-) & 0.39 & 0.65 & 0.52 & 0.54 & 0.39 \\
\hline WSI (-) & 0.19 & 0.55 & 0.72 & 0.65 & 0.24 \\
\hline
\end{tabular}




\section{FIGURE CAPTIONS}

Fig 1. Regionalisation units in (a) WaterGAP 2, used in the WSI by (Pfister et al. 2009), (b) used in this paper to calculate WSI CFs. The largest watersheds (Duero, Ebro, Tajo, Guadalquivir and Guadiana), coloured in both images, have been subdivided into sub-watersheds.

Fig 2. (a) WSI CFs at the sub-watershed regionalization level for (a) the current situation scenario, (b) the short-term scenario, (c) the mid-term scenario.

Fig 3. Standard deviation (a) and k-dispersion factor (b) of WSI under consideration of uncertainty.

Fig 4. Annual WSI under consideration of uncertainty. 


\section{FIGURES}

a)

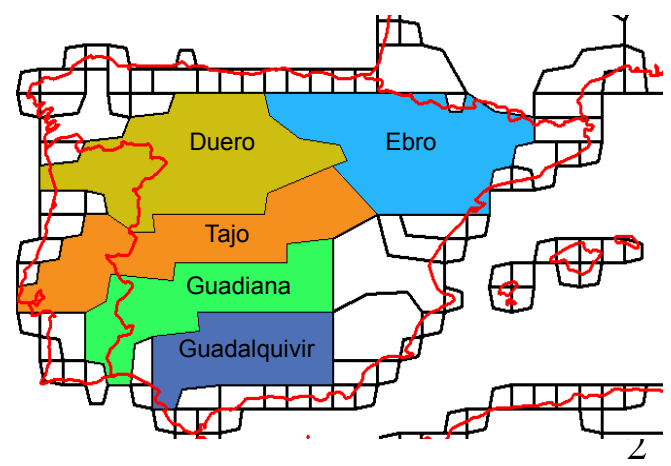

b)

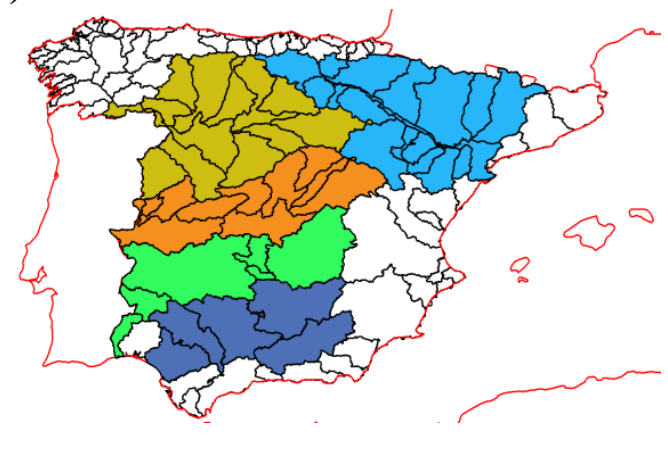

3 Fig 1.

4

5

a) WSI current situation

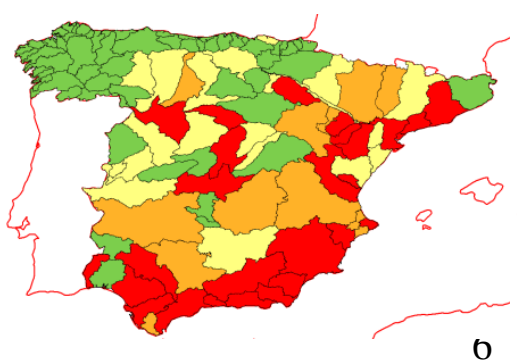

7 WSI $\left[\mathrm{m}^{3} / \mathrm{m}^{3}\right]$

8

9

Fig 2.

stress)
11

12

13

14

15

16

17 b) WSI short-term future

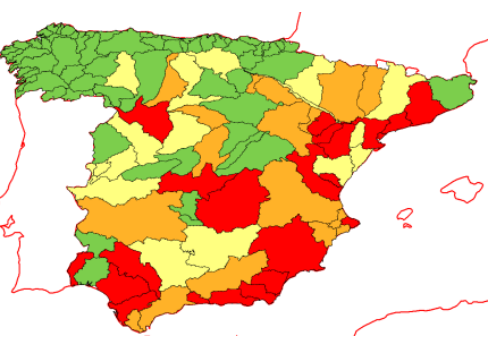

c) WSI mid-term future

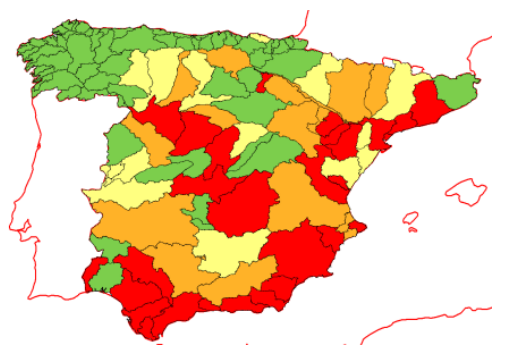

0.09-0.5 (mid stress) $\quad 0.5-0.91$ (high stress)

$>0.91$ (very high stress)

\section{0}

\section{a) Standard deviation}

2

$\leq 0.05$
$0.05-0.1$
$0.1-0.15$
$0.15-0.2$
$0.2-0.25$
$>0.25$

7

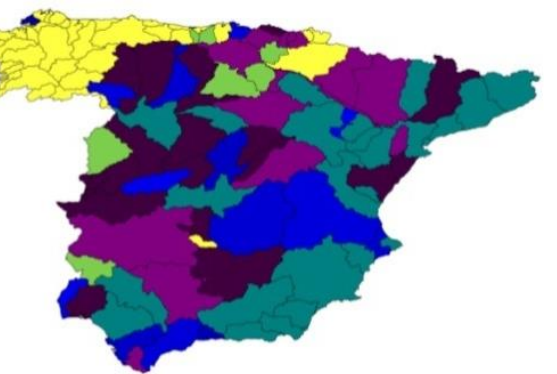

b) k-dispersion factor

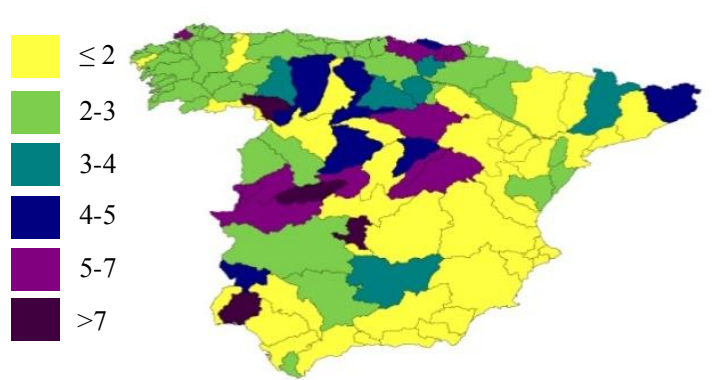

Fig 3. 
Author-produced version of the article published in International Journal of Life Cycle Assessment, 2015, №20(1), p. 128-138 The original publication is available at http://link.springer.com/article/10.1007/s11367-014-0803-5

Doi: 10.1007/s11367-014-0803-5

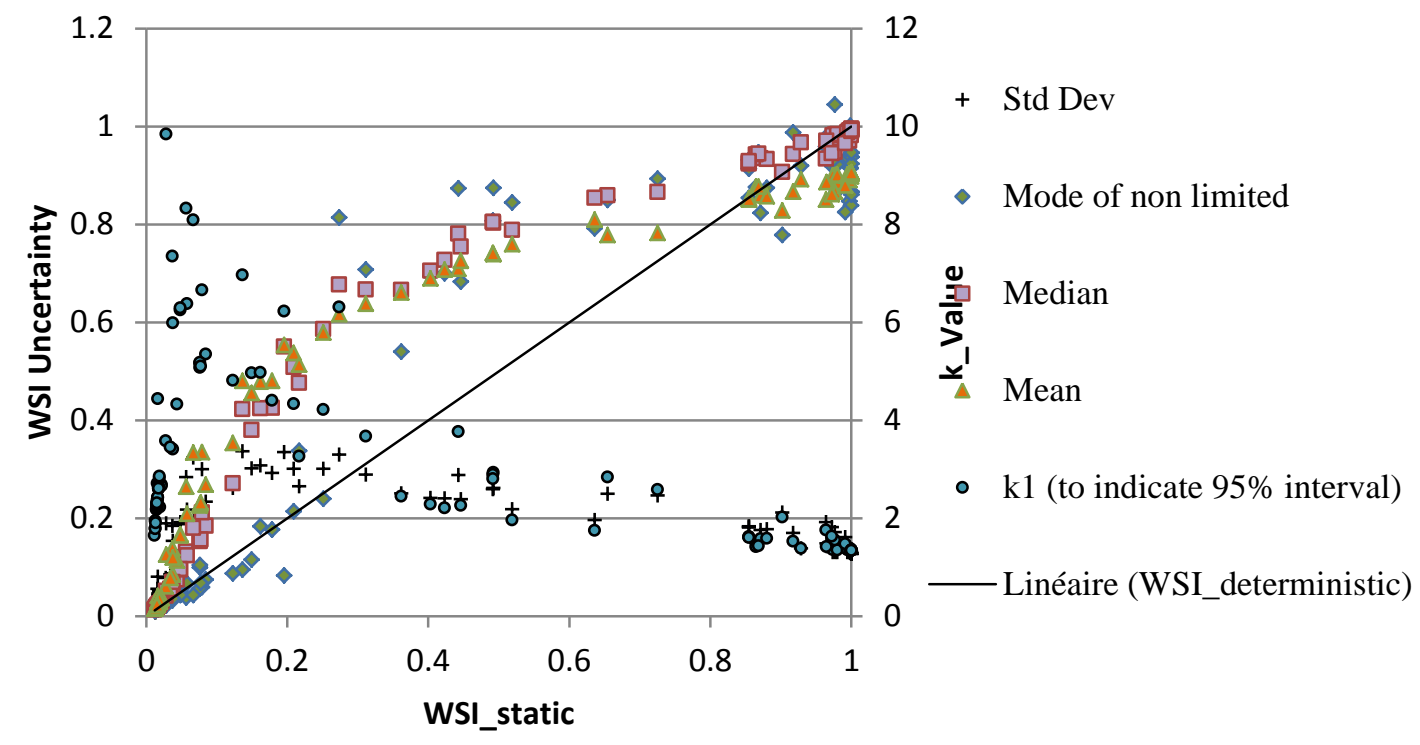

$19 \quad$ Fig 4. 